\title{
GIRL-CHILD EDUCATION FOR HEALTH LIVING: AN APPRAISAL
}

\section{Dr. I. G. USMAN}

\begin{abstract}
Girl-child education and school attendance are the focus of the United Nations agencies in recent years because education is the key to the advancement of girls and women, as World wide Hasli (2006) noted that globally, world vision has joined with communities to ensure that neither violence; disability nor other terms of discrimination will prevent women and girls from enjoying their rights. The Federal Government of Nigeria (FGN, 2004) in the national policy on education stated that education is a right and not a privilege for every citizen, whether male or female. It is against this backdrop that this paper attempts to appraise the girl-child education on the basis of improved life condition, healthy living and general development of individual and society. In pursing the goals of the Millennium Development Goals (MDGs), many nations of the world have put machinery in place, to encourage the girl-child education. This paper is interested in emphasising on girl - child education so as to actualise women potentials and those significant areas that contribute to the welfare and sustainability of the girl - child. The paper also advanced counselling strategies such as mentoring, modelling and value orientation which could serve as panacea for encouraging girl-child education in Nigeria.
\end{abstract}

Keywords: Girl-child, education, equal participation, healthy living, counseling strategies.

\section{Introduction}

We are in the period of escalating global interdependence and competition both of which affects formal education and the girl-child. Changes in economic competitiveness are creating an increasing demand for literate folk and technically skilled and oriented men and women. Amalu (2003) in Usman (2012) asserted that modern scientific and technological activities are since-qua-non to national economic empowerment and development through improved labour force capacities and the creating of new knowledge. The goals of national development needs to be identified, as they pertain the healthy living of individual citizen male or female as well as the sustainability of the environment. They include:

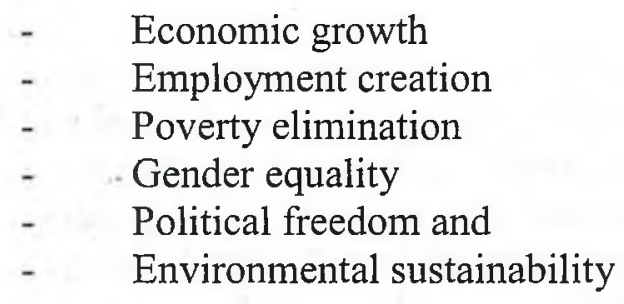

A part from general welfare males and females that improves as a result of attaining education, education makes women better care-givers and increase their efficiency in household health. They understand the dangers of poor hygiene and poor diets, can identify prevailing health problems and methods of preventing them. They can seek medical care and improve sanitation practice, thereby protecting their children from diseases like: Kwashiorkor, anaemia, rickets, HIV/AIDs, etc, which will make them less likely to die in infancy. According to Alamina (2001), good health that a women provides for the family is as a result of proper understanding of the need for balanced diet for the family. In agriculture, and educated woman is a better farm manager and producer of 
nutrients that body needs. She is able to read directives and apply farm inputs and medicare appropriately. She is able to administer drugs to farm animals (livestock, poultry and aquatics) and can be able to preserve products effectively and safely.

Educated women help their children to learn. We are in an information conscious and science and technology driven world, where children at a very early age want to know about space, our craft, computer etc. A woman need to be appropriately educated to be able to answer such questions which border on development of the nation socially, economically, politically, technologically, spiritually and culturally (Adebinpe and Mamon, 2001). Hence, this paper attempts to appraise the magnitude at which dividends of education of the girl-child can improve the welfare of women in general, which has received esoteric taste, among some parents in rural areas, especially. In recent years, a lot of efforts have been made by the Nigerian government towards promoting the education of the girl-child. UNESCO (2005) identified some attempts by Nigeria such as: the Universal Basic Education, 1999 and later in 2004, lowering of cut-off points for admission for girls into the secondary schools, scholarship in to science, technology and mathematics education (STMES); the promulgation of an edict banning the withdrawal of girls from schools for marriage; the National Policy on Education (revised, 2004); the production of blue-print on women education by the Federal Ministry of Education and the declaration of free education for girls in many states in Nigeria etc. This is why this paper attempts to emphasise on appraising the benefits of education to the girl-child education in Nigeria.

\section{Concept of Education}

Education, according to Rurtch (2006) in Balogun, Adeniji \& Adenigbagbe (2012) refers to a major force in economic, intellectual, social and cultural empowerment. Its value in bringing about character and attitudinal change ranks, as important as its ability to reshape human potential for desired development and that, the role of education in the over all development of a nation and an individual cannot be over emphasized.

Generally, education is aimed at promoting national unity, removing social inequalities, producing both middle and high level manpower for economic scientific and technological development, training for vocational competence, as well as promoting international understanding, self-realisation and ciovilised behavior.

Education, according to Abolarin (2009), is the transmission of what is worth while, invoking knowledge and understanding with the corruptive perspective to a learner, for the purpose of developing his or her potential to the maximum, so as to make him or her a responsible person. Basically, education is a process by training an individual systematically with the aim of developing his or her latent ability, to effect positive behavior changes, which would bring achievement of his or her life goals, to become a fulfilled citizen.

1. Equal Healthcare: Available evidence from Asia, Middle East, Africa and Nigeria (UNICEF, 1990) indicate that sex bias exists in the area of healthcare. Girls and women are said to enjoy lesser healthcare with various exploitative sexual practices. Therefore all efforts made to ensure equal healthcare for the girlchild, should be directed towards eliminating these practices. To ensure equal healthcare, alternative action through various health programmes, should be 
mounted to ensure equal coverage benefit for boys and girls. Programmes of immunization, treatment and other health matters, should address the issues of gender equality in health, in the following manner:

a. All health-related reports, surveillance and monitoring, should make efforts to produce gender-specific data on the health status of boys and girls.

b. All immunization projects in the state should be penetrated with adequate report to back up the coverage on sex.

c. Expand all women health educational programmes, information and service, such as family planning, EPI, Nutrition etc.

d. Enact edicts to eliminate traditional custom and rites harmful to girls' physical, mental and emotional health through advocacy programmes/actions.

e. Increase the means of accessibility to community-based childcare to include fuel, water and sanitation services, for poor household and rural areas.

2. Equal Nutrition for Girls: The nutritional equality between boys and girls must be addressed through culture and economic levels of the families. This is done through:

a. Educating fathers and mothers through series of orientation on the importance of providing adequate food for girl-child.

b. Collecting data on the nutritional status of children by gender and using such information to design appropriate nutritional programmes for girls.

c. Sensitizing and training those involved in family health and childcare to ensure that girl-child receives her fair share of food and other resources essential for her growth.

d. Exploring appropriate measures or soft bans small scale technology projects to process, store and conserve food.

3. Equal Employment Opportunities for Girls: According to UNESCO (1998), various survey were conducted and disparity exists in the number of hours that children perform in and around the home.

4. Equal Educational Rights and Opportunities: In Nigeria, the disparity in access to education continue to exist in favour of males; while correspondingly high literacy rate persists amongst females: According to statistics available in 1990, the female literacy rate was estimated at about 37.65 percent: which when compared with 62.35 percent for males is relatively low (UNICEF, and Federal Ministry of Health and Social Development 1990). This means that 26.23 million of the estimated 43.9 million women in Nigeria are illiterate. This high illiteracy rate among women in Nigeria is attributed to historical, social and cultural antecendents such as stereotyping, forced and early marriage, thereby relegating women to the background in education, social, political and employment sectors. The enrolment trend into primary schools for girls in Nigeria has remained consistently lower than that for boys while attrition rate for girls has always been higher than that of boys. In order to remove some of these constraints and ensure participation in education, strategies are designed mainly towards, increasing the 
availability of education by expanding the number of school places for girls (supply); and improving the accessibility of education by increasing the benefits and reducing the cost of schooling for girls and their families (demand).

\section{Counseling Strategies for Addressing gender disparity in Nigeria}

Counseling is defined as face to face interaction between a counselor who is trained and experienced in the application of psychological principles in assisting individuals and a client who is having a challenge educationally, vocationally or personal-socially. It is seen as a process of assisting individuals increase in adaptive behaviours and decrease in maladaptive anti-social and unacceptable behaviours. Here, the counselor provides the client with the necessary clues, information, data and encouragement that would enable him/her resolve his challenges by himself or in relation with others.

Counseling strategies are therefore necessary in addressing the issue of girl-child education.

Among the appropriate counselling strategies for this purpose include: Mentoring/Role Modelling, Rewards, Reinforcement (3Rs), Peer counseling, Value-Orientation, Empowerment and counseling Entreprenuerial strategies, strategies towards political awareness, participation and patriotism, strategies toward educational excellence, strategies for interpersonal relationships (communication skills) and bibliotherapy.

Mentoring/Live Modelling: Mentoring and live modeling are similar counseling strategies. Here the counselor carefully selects an "ideal" personally such as educated women who would play the role of mentors or live model to the individual(s) illiterate girls and parents who have negative attitude towards education. In this case, the uneducated girls and parents learn new ideas from the educated women, through initiation. It may be inform of teaching, advocacy campaign. The personality characteristics of the educated women could be emulated by uneducated ones, while parents could be attracted or motive to send their girls to school.

Recognition, Rewards and Reinforcement (3R): The government should identify and recognize those girls that attend school and give them some incentives, scholarship award, free learning materials, so as to serve as impetus or reinforcement, to increase their spontaneous interest in school education. In this way, parents will be relieved of school fees and other financial burden on scholarsism.

Individual/Group Counselling: In this strategy, the counselor should hold counseling sessions with individual girls and sometimes in a group in various communities. This could be organized by liaising with community leaders, local counselors, chairman, teachers, social workers etc. The stakeholders should talk on the advantages and disadvantages of formal education to the illiterate girls and their parents. The future of girl-child education should be emphasized.

Entrepreneurial Counselling: The counselor should liase with stakeholders to train educated girls in various enterprising skills that can make females to be sustainable and financially independent such as sawing, tie and dye, knitting, small scale industry etc. 
Value Orientation: The counselor should collaborate with stakeholders to educated women folk on human rights, child's rights, norms, rules, regulations and constitute authority and law of the land. By so doing, the girl-child and women be oriented towards value awareness including formal education.

Political Awareness: Liaising with stakeholders in the community, the counselor should launch advocacy campaign, mobilization and sensitization of the girl-children, and their parents. They should be sensitized on the place or role of formal education in politics and democracy in Nigeria, by emphasizing the ability to participate in politics, election, leadership positions, civic responsibilities, effective citizenship, government expenditure, budget, allocation or money to various localities etc, emphasizing that without education, citizens can not effectively participate in democracy and illiterate ones stand more to be at the disadvantage.

Bibliotherphy: This calls for collaborating with the clergy men and women who can act as resource persons in the school, community, mosques, churches, social clubs and societies. These stakeholders should use their pastoral competence to sensitise girls and their parents, on the role of education in religious teachings and propagation. Adherents of religious denominations are more likely to listen to their Pastors and Imams than any other person.

\section{Conclusion}

In an epitome, situation of the girl-child in various perspectives in order to appreciate the need for improving the condition of females becomes significantly important. It is realized that efforts to promote the rights and opportunities of the girl-child must ensure equity in providing basic health care, nutrition, education and employment. This paper believes that education is the key to ensuring equal rights and opportunities of the girlchild. Therefore, basic literacy should be reinforced to ensure successful completion of primary school by girls. Therefore, biological and social conditions and attitudes towards the girl-child need to be changed in order to achieve ultimate level of women empowerment, national development and sustainability.

\section{Recommendations}

Against the backdrop that the girl-child education. should be given a pride of place in Nigeria, the following recommendations are proffered, viz a viz:

1. Qualified professionals and experienced counselors should be used by government at local, state and federal levels, non-governmental agencies and organizations to apply appropriate counseling strategies in addressing issues of gender polarity and disparity to ensure equal participation in all sectors of economy.

2. Enforced law by enacted against withdrawal of girls from schools.

3. Girls and women should be given formal and informal education to empower them through skills acquisition programmes and be given soft loan for entrepreneurship to reduce level or poverty, illiteracy and unemployment or under employment.

4. Community leaders, parents should undergo value-orientation, community based counseling and dialogue with counselors, social workers so that they receive sensitization on the values of the girl-child education. 
5. Advocacy enlightenment campaign and clarion call should be launched by the media to sensitise the public, regarding the significance and important of the girlchild education.

6. More females institutions should be built and free education be given to females at all level so as to encourage females and parents in school education.

7. Women should be encouraged to organize women clubs in schools, and cooperative societies in various communities so as to encourage females in active participation with their male counterparts. 


\section{References}

Abdul, A. \& Popoola, F. R. (2010): Girl-Child education for sustainability and development: Constraints and remeaches. In Ogungbe, E. O.; Apara, S. A. E.; Mohammad, M. H. \& Talla, N. S. (eds.) Education for Sustainable Development in Nigeria, Jos: Smart Print Production.

Abolarin, E. E. (2012): Education and Sustainable Development: Challenges of girl-child education. In Ogungbe, E. O.; Apara, S. A. E.; Mohammad, M. H. \& Talla, N. S. (eds.) Education for Sustainable Development in Nigeria, Jos: Smart Print Production.

Adebinpe, A. O. \& Manon, S. (2001): Women in Science, Technology and Mathematics in Nigeria: A Review of gender representation in College of Education. In Busari, O. O. (eds.) Preceeeding of 42th Annual National Conference of Science Teachers' Association of Nigeria, Lagos: Heinemann Education Books (Nigeria) Plc.

Akinpela, F. O. (2007): The International Journal of the Humanities, 5 (3): 5 - 9 retrieved on January, 18, 2010 from www.humanities-iournal.com

Alamina, J. I. (2001): An Impediment to women in Science, Cultural Influence and the way forward. In Busari, O. O. (eds.) Preceeeding of 42 th Annual National Conference of Science Teachers' Association of Nigeria, Lagos: Heinemann Education Books (Nigeria) Plc.

Amala, I. (2003): Nigeria: Problem of girl-child education accessed from http://www.cyc.net.203

Balogun, M. A.; Adeniyi, O. \& Adenighagbe, O. G. (2012): Equal gender education for national development. A paper presented at the International Conference of Collaborative of Education Faculties in West Africa at Ibrahim Badamasi Babangida between $25^{\text {th }}-28^{\text {th }}$ November.

Federal Government of Nigeria (2004): National Policy on Education, Lagos: Government Press.

Gurin, R. (1999): Strategies for ensuring equal rights and opportunities for the girl-child in Usman, I. G. (2007) An Exploratory study of incidence, typology and counseling need manifestation of street children (Almajiri) in Northern parts of Nigeria, A $\mathrm{PhD}$ Thesis submitted to the Department of Counselling and Educational Psychology, University of Abuja, Nigeria.

Hashi, F. (2006): Creating an enabling environment for the advancement of women and girls. A briefing paper to the United Nations Commission on women status at its $50^{\text {th }}$ session.

Iwuama, B. C. \& Ekwe, A. O. (2012): Counselling Strategies for addressing militancy and social restiveness in Nigeria. A paper presented at the $36^{\text {th }}$ Annual Intemational Conference Organised by the Counselling Association of Nigeria (CASSON) held at Obafemi Awolowo University, lle-Ife Osun State, Nigeria, between $27^{\text {th }}-31^{\text {st }}$ August. 
Kareem, S. O. (2008): Gender equalization and the Universal Basic Education in Nigeria. A case study of the girl-child, In Journal of Education Research and Politics, 3 (1): 58 -66 .

Rurtch, B. (2006): Education law and social justice in Oduran, A. (eds.) E. L. G. access to Education as Social Justice, Netherlands Springer, pp. $83-94$.

UNESCO, (1998): The State of Education in Nigeria, Abuja: UNESCO.

UNESCO, (2005): Education of girls and women in Africa, UNESCO.

UNICEF \& Federal Ministry of Health \& Social Development (1990): The Nigerian Child, now and in the future, Lagos: Government Press.

UNICEF (2003): Teachers Talking about learning. Retrieved on December, 30, 2012 from http://www.unicef.org/teachers/forum/0203.htm

Usman, I. O. (2007): An exploration study of incidence, typology and counseling needs manifestations of street children (almajiri) in Northern Part of Nigeria. A PhD Thesis submitted to the Department of Counselling and Educational Psychology, University of Abuja, Nigeria.

Usman, I. G. (2012): Guidance Services: Theory and Practice, Abuja: UTC Publishers. 